\title{
Pharmacist-led interventions might improve quality of life among older adult patients receiving warfarin treatment in rural areas: results from a randomized controlled trial
}

Research article

Keywords:

Posted Date: November 23rd, 2020

DOI: https://doi.org/10.21203/rs.2.23204/v2

License: (1) This work is licensed under a Creative Commons Attribution 4.0 International License.

Read Full License

Version of Record: A version of this preprint was published at Scientific Reports on November 9th, 2021.

See the published version at https://doi.org/10.1038/s41598-021-01394-0. 


\section{Abstract}

The authors have requested that this preprint be withdrawn due to author disagreement.

\section{Full Text}

The authors have withdrawn this preprint from Research Square. 